\title{
Milk Fat Globule Epidermal Growth Factor-8 Blockade Triggers Tumor Destruction Through Coordinated Cell-autonomous and Immune- mediated Mechanisms
}

\section{Citation}

Jinushi, Masahisa, Marimo Sato, Akira Kanamoto, Akihiko Itoh, Shigenori Nagai, Shigeo Koyasu, Glenn Dranoff, and Hideaki Tahara. 2009. Milk fat globule epidermal growth factor-8 blockade triggers tumor destruction through coordinated cell-autonomous and immune-mediated mechanisms. The Journal of Experimental Medicine 206(6): 1317-1326.

\section{Published Version}

doi://10.1084/jem.20082614

\section{Permanent link}

http://nrs.harvard.edu/urn-3:HUL.InstRepos:8148891

\section{Terms of Use}

This article was downloaded from Harvard University's DASH repository, and is made available under the terms and conditions applicable to Other Posted Material, as set forth at http:// nrs.harvard.edu/urn-3:HUL.InstRepos:dash.current.terms-of-use\#LAA

\section{Share Your Story}

The Harvard community has made this article openly available.

Please share how this access benefits you. Submit a story. 


\section{Milk fat globule epidermal growth factor-8 blockade triggers tumor destruction through coordinated cell-autonomous and immune-mediated mechanisms}

\author{
Masahisa Jinushi, ${ }^{1}$ Marimo Sato, ${ }^{1}$ Akira Kanamoto, ${ }^{1}$ Akihiko Itoh, ${ }^{1}$ \\ Shigenori Nagai, ${ }^{2,3}$ Shigeo Koyasu, ${ }^{2}$ Glenn Dranoff, ${ }^{4}$ and Hideaki Tahara ${ }^{1}$ \\ 'Department of Surgery and Bioengineering, Advanced Clinical Research Center, Institute of Medical Science, University \\ of Tokyo, Tokyo 108-8639, Japan \\ ${ }^{2}$ Department of Microbiology and Immunology, Keio University School of Medicine, Tokyo 160-8582, Japan \\ ${ }^{3}$ Core Research for Evolutional Science and Technology, Japan Science and Technology Agency, Tokyo 102-0075, Japan \\ ${ }^{4}$ Department of Medical Oncology and Cancer Vaccine Center, Dana-Farber Cancer Institute and Department of Medicine, \\ Brigham and Women's Hospital and Harvard Medical School, Boston, MA 02115
}

\section{CORRESPONDENCE}

Hideaki Tahara:

tahara@ims.u-tokyo.ac.jp

Abbreviations used: 5-FU, 5-fluorouracil; BMDC, bone marrow-derived dendritic cell; MFG-E8, milk fat globule epidermal growth factor-8; NODSCID, nonobese diabetic-severe combined immunodeficiency; VEGFR-2, antivascular endothelial growth factor receptor-2.
Cancer pathogenesis involves not only the cellautonomous defects that arise from alterations in oncogenes and tumor suppressors but also the impact of host antitumor responses (1). Cancer cells that have escaped immune control are selected for the ability to exploit factors present in the tumor microenvironment to further disease progression (2-4). Among this array of soluble moieties, inflammatory cytokines including TNF- $\alpha$, IL-6, and IL-1 $\beta$ play key roles through triggering NF- $\mathrm{kB}-$, STAT-3-, and MyD88dependent pathways (5-8).

GM-CSF is another cytokine frequently produced in the tumor microenvironment, where it may contribute to either tumor protection or promotion (9). Through studies of GM-CSFdeficient mice, we identified milk fat globule epidermal growth factor-8 (MFG-E8) as a critical determinant of the pro- and antiinflammatory activities of the cytokine (10). MFG-E8 is a secreted phosphatidylserine-binding protein that signals through $\alpha_{v} \beta_{3}$ and $\alpha_{v} \beta_{5}$ integrins (9-12). Under steady-state conditions, GM-CSF induces MFGE8 expression in mononuclear phagocytes, enabling the efficient uptake of apoptotic cells, the production of TGF- $\beta$ and CCL22, and the maintenance of FoxP3 ${ }^{+} \mathrm{T}$ reg cells (10). Under conditions of cellular stress, however, the ligation of Toll-like receptors dampens MFG-E8 expression, whereupon $\mathrm{GM}-\mathrm{CSF}$ elicits $\mathrm{CD} 4^{+}$and $\mathrm{CD} 8^{+}$effector $\mathrm{T}$ cells through an MFG-E8-independent pathway. Thus, the levels of MFG-E8 present in the tumor microenvironment might modulate the functions of GM-CSF during carcinogenesis.

In malignant melanoma, MFG-E8 expression is increased in tumor cells and/or infiltrating

2009 Jinushi et al. This article is distributed under the terms of an Attribution-Noncommercial-Share Alike-No Mirror Sites license for the first six months after the publication date (see http://www.jem.org/misc/terms.shtml). After six months it is available under a Creative Commons License (Attribution-Noncommercial-Share Alike 3.0 Unported license, as described at http://creativecommons .org/licenses/by-nc-sa/3.0/). 
myeloid elements upon progression to the vertical growth phase, the stage in which melanoma cells acquire the competence for invasion and dissemination $(12,13)$. In a mouse melanoma model, MFG-E8 augmented tumorigenicity and metastatic capability through Akt- and Twist-dependent mechanisms (12). MFG-E8 enhanced melanoma cell resistance to apoptosis, induced an epithelial-to-mesenchymal transition, and stimulated invasion and angiogenesis. MFG-E8 also contributed to local immune suppression by evoking FoxP $^{+} \mathrm{T}$ reg cell infiltrates and suppressing Th1 reactions and $\mathrm{NK}$ and $\mathrm{CD}^{+} \mathrm{T}$ cell cytotoxicity.

Because MFG-E8 is expressed at high levels in diverse tumor types $(14,15)$, including melanoma, this soluble protein might serve as a general target for cancer therapy. In contrast to most oncologic treatments, which primarily address either the tumor or host separately, MFG-E8 antagonists might affect both compartments. Indeed, shRNA knockdowns of MFG-E8 sensitized tumor cells to cytotoxic agents and small molecule inhibitors of receptor tyrosine kinases in vitro, whereas MFG-E8 blockade with a dominant-negative mutant potentiated tumor immunity generated with irradiated, GMCSF-secreting tumor cell vaccines $(10,12)$. Based on these results, we hypothesized that systemic targeting of MFG-E8 might contribute to tumor destruction in several complementary ways. In this paper, we show that antibodies to MFG-E8 cooperate with conventional cancer therapies to effectuate sustained control of established mouse tumors through the coupling of cell-autonomous and host-mediated pathways.

\section{RESULTS}

\section{Combinatorial therapy with systemic MFG-E8 blockade}

To explore the therapeutic potential of anti-MFG-E8 antibodies, we first characterized the moderately immunogenic MC38 colon carcinoma model that is syngeneic to C57BL/6 mice. At $10 \mathrm{~d}$ after intradermal inoculation, when tumors were well established $\left(\sim 25 \mathrm{~mm}^{2}\right)$, the systemic administration of gemcitabine, a cytotoxic agent with modest activity in patients with colon carcinoma (16), afforded a small delay in MC38 tumor growth in a dose-dependent fashion (Fig. $1 \mathrm{~A})$. Although a blocking anti-MFG-E8 mAb (17) displayed minimal antitumor activity when infused alone, combination treatment with gemcitabine resulted in tumor regressions that were sustained throughout the duration of the study (4 mo). A rabbit polyclonal anti-MFG-E8 serum (18) showed comparable efficacy (Fig. 1 B), whereas an isotype control $\mathrm{mAb}$ was inactive (not depicted), establishing the specificity of the response. Synergistic antitumor effects were also obtained when the anti-MFG-E8 antibodies were administered beginning 3 or $7 \mathrm{~d}$ after gemcitabine but not when infused before chemotherapy, indicating that the sequence of the combination was important for activity (Fig. S1).

Systemic anti-MFG-E8 antibodies similarly enhanced the therapeutic potency of 5-fluorouracil (5-FU) and CPT-11 (Fig. $1 \mathrm{C}$ ), two agents frequently used in the treatment of advanced colon carcinoma patients (16). As with gemcitabine, these combination therapies achieved prolonged tumor con- trol, in contrast to the limited impact of individual agents. MFG-E8 blockade also intensified the activity of an epidermal growth factor receptor tyrosine kinase inhibitor and an antivascular endothelial growth factor receptor-2 (VEGFR-2) $\mathrm{mAb}$ (Fig. 1 D). Additionally, a short course of radiation therapy directed toward subcutaneous MC38 lesions was rendered more efficacious when combined with anti-MFG-E8 antibodies (Fig. 1 E). Synergistic effects of anti-MFG-E8 antibodies and chemotherapy were similarly observed in the poorly immunogenic B16 melanoma model. In this system, combinations of MFG-E8 blockade with doxorubicin, etoposide, or dacarbazine achieved significant tumor control, although gemcitabine proved inactive (Fig. $1 \mathrm{~F}$ and not depicted). Moreover, the combined administration of anti-MFG-E8 antibodies and doxorubicin also triggered the destruction of established EL-4 thymomas (Fig. S2). Collectively, these experiments reveal the ability of systemic MFG-E8 blockade to intensify the antitumor effects of conventional oncologic therapies in diverse tumor models.

\section{MFG-E8 blockade enhances drug-induced apoptosis}

Because standard cancer treatments displayed only modest single-agent activity against various types of tumors, we wondered whether the anti-MFG-E8 antibodies might modulate tumor cell killing. In this context, we previously showed that MFG-E8 triggered Akt activation in tumor cells through $\alpha_{v} \beta_{3}$ integrin signaling, which resulted in an attenuation of etoposide-induced death (12). In accordance with these findings, MFG-E8 was not detectable in MC38 and B16 cells at baseline, whereas cells that survived an overnight exposure to diverse chemotherapeutic drugs manifested significant MFG-E8 expression, which was evident intracellularly, at the surface membrane, and in culture supernatants (Fig. 2, A and B; and not depicted). $\gamma$ irradiation also induced MFG-E8 surface expression on EL-4 thymoma (EG.7OVA) cells (Fig. 2 C). Furthermore, stable drug-resistant variants of MC38 cells, which were generated through prolonged exposure to escalating concentrations of gemcitabine, CPT-11, or 5-FU in vitro, and similarly derived doxorubicin-resistant B16 cells demonstrated much higher levels of MFG-E8 compared with the parental tumor cells (Fig. 2 D and not depicted).

Consistent with an antiapoptotic function for surface and/ or secreted MFG-E8, the addition of anti-MFG-E8 mAbs but not irrelevant control antibodies potentiated the killing of MC38 cells with gemcitabine and 5-FU, as revealed by the enhanced expression of annexin V (Fig. 2 E). The addition of rabbit polyclonal anti-MFG-E8 serum manifested comparable effects (unpublished data). The induction of apoptosis with the combined therapy also resulted in a loss of mitochondrial membrane potential (unpublished data). Moreover, the combination therapies triggered increased levels of tumor apoptosis in vivo. MC38 tumors harvested from mice that received gemcitabine plus anti-MFG-E8 antibodies showed enhanced caspase 3 activation as compared with tumors isolated from mice treated with either agent alone (Fig. 2 F). Similarly, 
B16 melanomas manifested elevated caspase 3 activation after combined dacarbazine and MFG-E8 blockade. These results support the idea that MFG-E8 blockade compromises tumor cell viability in a cell-autonomous fashion, although the increased caspase activation in vivo might partially reflect the death of stromal elements within the tumor microenvironment. The anti-MFG-E8 antibodies may also attenuate tumor angiogenesis (18), which might contribute to tumor cell death as well. Collectively, these results reveal a role for MFG-E8 in mediating resistance to cytotoxic therapy and suggest that antiMFG-E8 antibodies might serve as a complementary strategy to intensify drug-induced tumor cell killing.

\section{Combinatorial therapy with MFG-E8 blockade stimulates T cell immunity}

Because MFG-E8 plays a key role in T reg cell homeostasis (10), we investigated whether the antitumor activities of combined chemotherapy and MFG-E8 blockade might also involve host immunity. In accordance with this idea, antiMFG-E8 antibodies failed to increase the minimal killing of MC38 cells achieved with gemcitabine in immunodeficient nonobese diabetic-severe combined immunodeficiency (NOD-SCID) mice (Fig. 3 A). Moreover, antibody depletion experiments established that $\mathrm{CD}^{+}$and to a lesser extent $\mathrm{CD}^{+} \mathrm{T}$ cells, but not NK cells, were required in wild-type
A

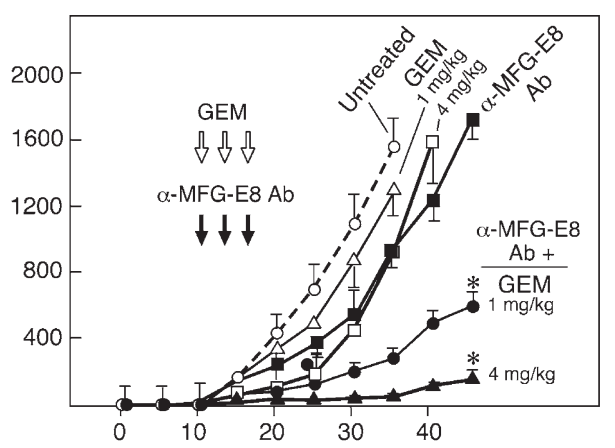

C

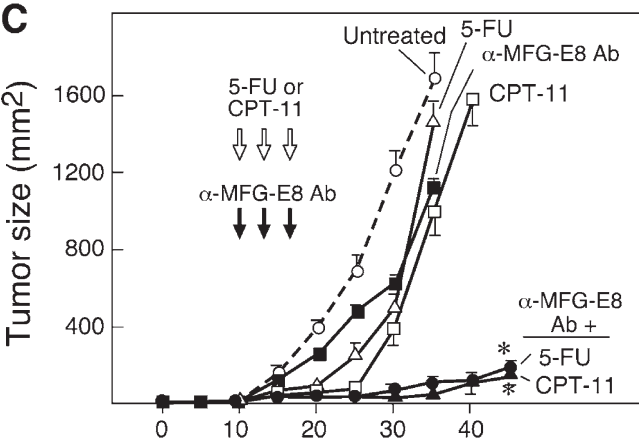

$\mathbf{E}$

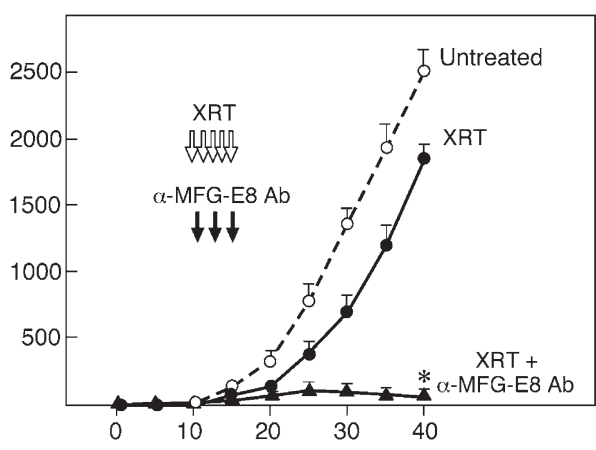

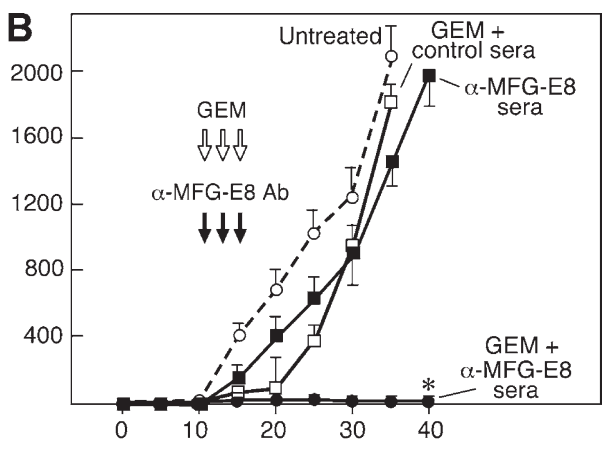
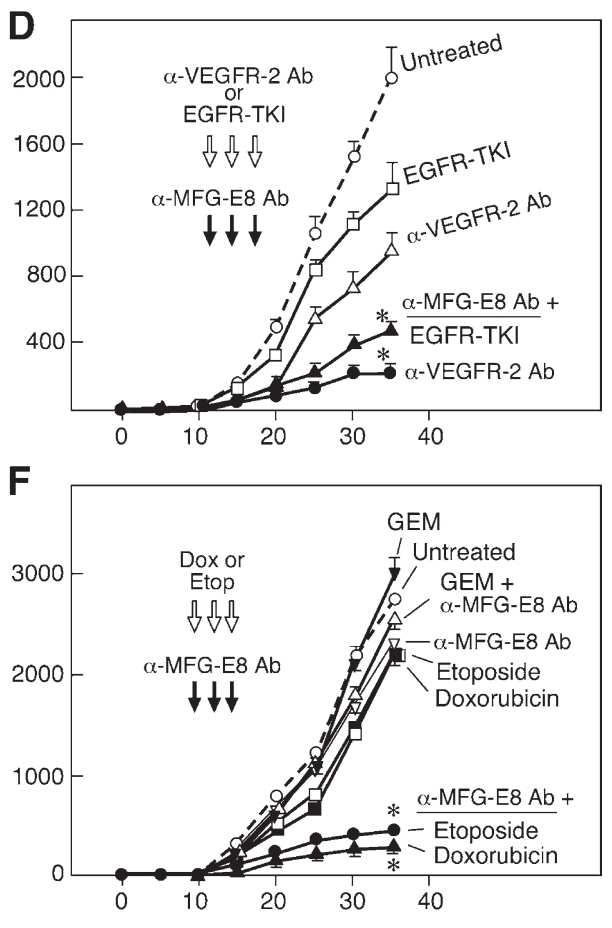

Days

Figure 1. MFG-E8 antibody blockade synergizes with cytotoxic therapies to mediate tumor destruction. (A) Established MC38 carcinomas (25 mm²) were treated with systemic gemcitabine (GEM) and/or an anti-MFG-E8 mAb, as indicated. (B) Same conditions as in A, but with rabbit anti-MFG-E8 sera. (C) Established MC38 carcinomas were treated with 5-FU or CPT-11 with or without anti-MFG-E8 mAb. (D) Established MC38 carcinomas were treated with anti-VEGFR-2 mAb DC101 or EGFR-TKI AG490 with or without anti-MFG-E8 mAb. (E) Established MC38 tumors were treated with local irradiation (XRT) with or without systemic anti-MFG-E8 mAb. (F) Established B16 melanomas (25 mm²) were treated with systemic doxorubicin, etoposide, or GEM with or without anti-MFG-E8 mAb. Each experiment was performed with five mice per group, and similar results were observed for each panel in five independent experiments. Shown are the means \pm SEM per cohort for a representative experiment. ${ }^{*}, \mathrm{P}<0.05$ between a treatment group and control. 
mice for tumor destruction with the combination therapy, although the antitumor effects became significant compared with gemcitabine alone $40 \mathrm{~d}$ after combined therapy even with $\mathrm{CD}^{+} \mathrm{T}$ cell depletion (Fig. $3 \mathrm{~B}$ ). These findings suggest that the cell autonomous modes of tumor cell killing with MFG-E8 blockade are not sufficient to maintain durable control of the established cancers. Consistent with a key role for $\mathrm{T}$ cells in the generation of long-lived and specific protective immunity, treated mice rejected a subsequent lethal challenge with MC38 tumor cells but not B16 melanoma or MCA-205 fibrosarcoma cells (Fig. 3 C).

To characterize the $\mathrm{T}$ cell responses stimulated with treatment, we isolated tumor-infiltrating lymphocytes from regressing MC38 lesions. Although the proportions of total $\mathrm{CD}^{+}$and $\mathrm{CD}^{+} \mathrm{T}$ cells did not vary as a function of therapy, anti-MFG-E8 antibodies alone or in combination with CPT-11 significantly reduced the numbers of intratumoral Foxp $3^{+}$ T reg cells (Fig. 4 A). Although chemotherapy alone had no impact on $T$ reg cell numbers, combined treatment with antiMFG-E8 antibodies decreased T reg cell numbers in the spleen as well (Fig. $4 \mathrm{~A}$ ). The $\mathrm{T}$ reg cells that were recovered after
MFG-E8 blockade, however, did not manifest impaired function on a per cell basis, as assessed in standard in vitro suppression assays (unpublished data). These findings extend our earlier demonstration that MFG-E8 is an important determinant of antitumor $\mathrm{T}$ reg cell numbers $(10,12)$.

The combination treatment, but not anti-MFG-E8 antibodies alone, markedly increased $\mathrm{CD} 4^{+}$and $\mathrm{CD}^{+}$effector $\mathrm{T}$ cell activation and function. This stimulation resulted in high levels of surface CD44, IFN- $\gamma$ production, and tumor-specific cytotoxicity (Fig. 4, B-D). The combination therapy also augmented the total levels of circulating IgG2a and IgG2b antibodies, which might contribute to tumor destruction through Fc-dependent cytotoxicity (Fig. S3). These results highlight the synergy between systemic MFG-E8 blockade and chemotherapy for boosting multiple antitumor effector mechanisms.

\section{Anti-MFG-E8 antibodies enhance dendritic cell cross-presentation of tumor antigens}

Because MFG-E8 promotes the uptake of apoptotic cells by mononuclear phagocytes $(10,19-21)$, we next characterized the impact of chemotherapy and MFG-E8 blockade on

A
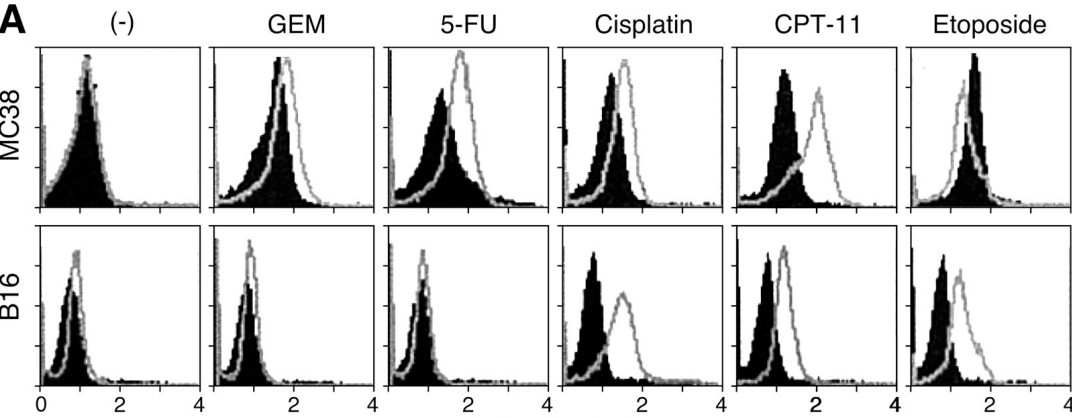

B
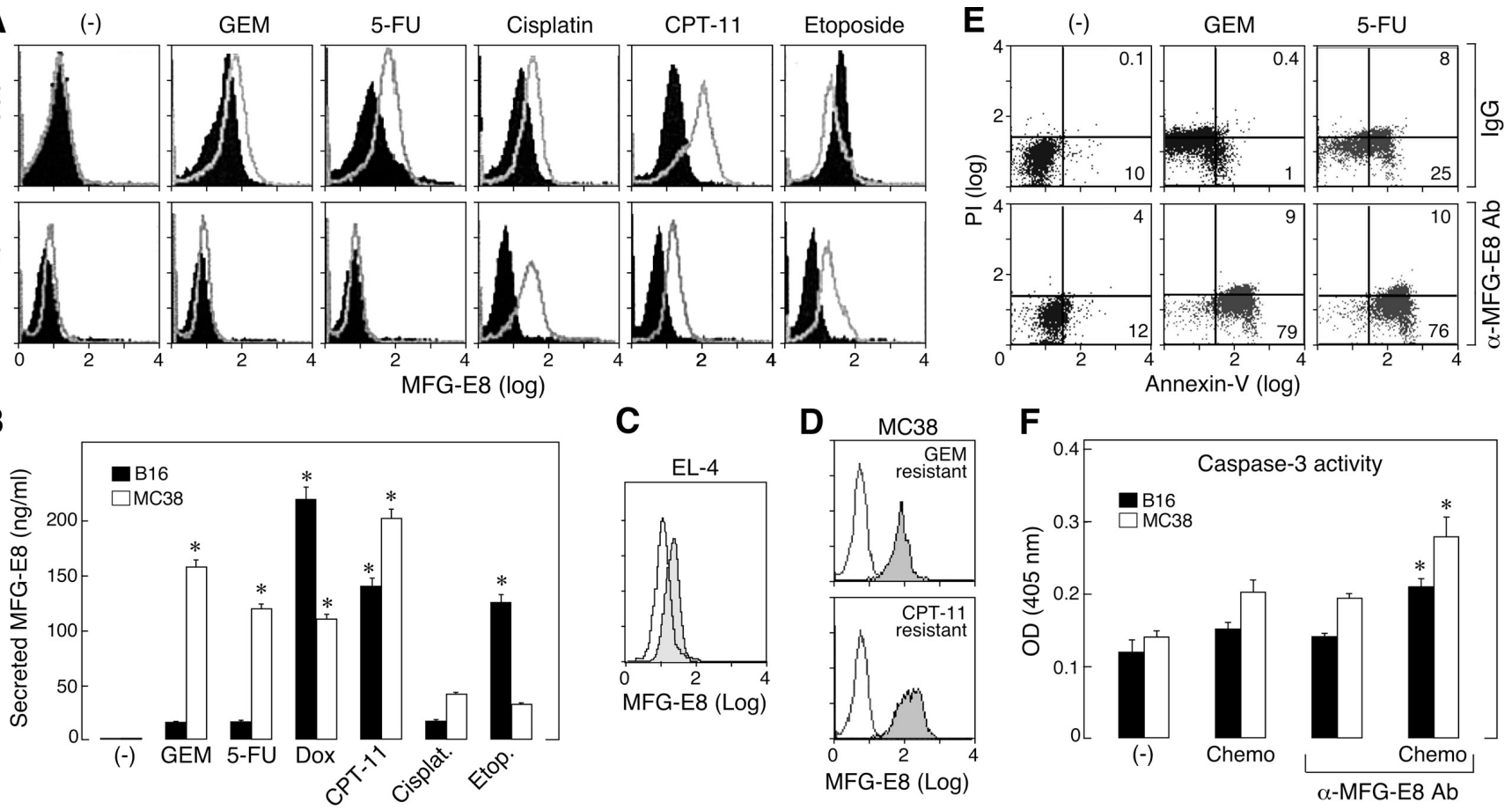

Figure 2. Drug-resistant tumor cells express MFG-E8. (A) MC38 carcinoma and B16 melanoma cells were treated with various cytotoxic agents under serum-free condition for $24 \mathrm{~h}$, and intracellular MFG-E8 expression in viable cells (annexin $\mathrm{V}^{-}$/propidium iodide ${ }^{-}$) was determined with flow cytometry. The shaded and open histograms represent the levels of expression on untreated and treated cells, respectively. Gemcitabine (GEM) and 5-FU accomplished minimal killing of B16 cells (not depicted). (B) MFG-E8 levels in culture supernatants from A were measured with ELISA. (C) EL-4 thymoma cells were treated with $\gamma$ irradiation (100 Gy), and MFG-E8 expression in viable cells (annexin $\mathrm{V}^{-}$/propidium iodide ${ }^{-}$) was determined with flow cytometry. (D) Stable drug-resistant variants of MC38 were generated and tested for MFG-E8 expression with flow cytometry (shaded histogram). The staining with isotype control antibodies is also shown. (E) MC38 carcinoma cells were exposed to GEM or 5-FU in the presence of anti-MFG-E8 mAb or isotype control as in $A$, and cell viability was determined with flow cytometry (percentages are shown). (F) Established MC38 and B16 tumors (25 mm²) were treated with GEM or dacarbazine, respectively, with or with systemic anti-MFG-E8 mAb as in Fig. 1. 4 d after completion of therapy, tumor homogenates were prepared and assayed for caspase 3 activation with ELISA. Presented data are representative of three independent experiments with similar results. Means \pm SEM are shown in $B$ and $F .{ }^{*}, P<0.05$ between the treatment and control. 
antigen-presenting cells. Although the combination treatment did not influence the proportions of macrophages (CD11 $\mathrm{b}^{+}$ Gr- $1^{-}$) or myeloid-derived suppressor cells $\left(\mathrm{CD} 11 \mathrm{~b}^{+} \mathrm{Gr}-1^{+}\right)$ that were isolated from regressing MC38 colon tumors (Fig. S4), the numbers of CD $11 b^{+}, \mathrm{CD} 11 \mathrm{c}^{+}$dendritic cells were significantly increased, and these cells expressed high levels of the co-stimulatory molecule CD86 (Fig. 5 A). As bone marrowderived dendritic cells (BMDCs) efficiently phagocytosed chemotherapy-exposed MC38 and B16 cells in vitro (Fig. S5),
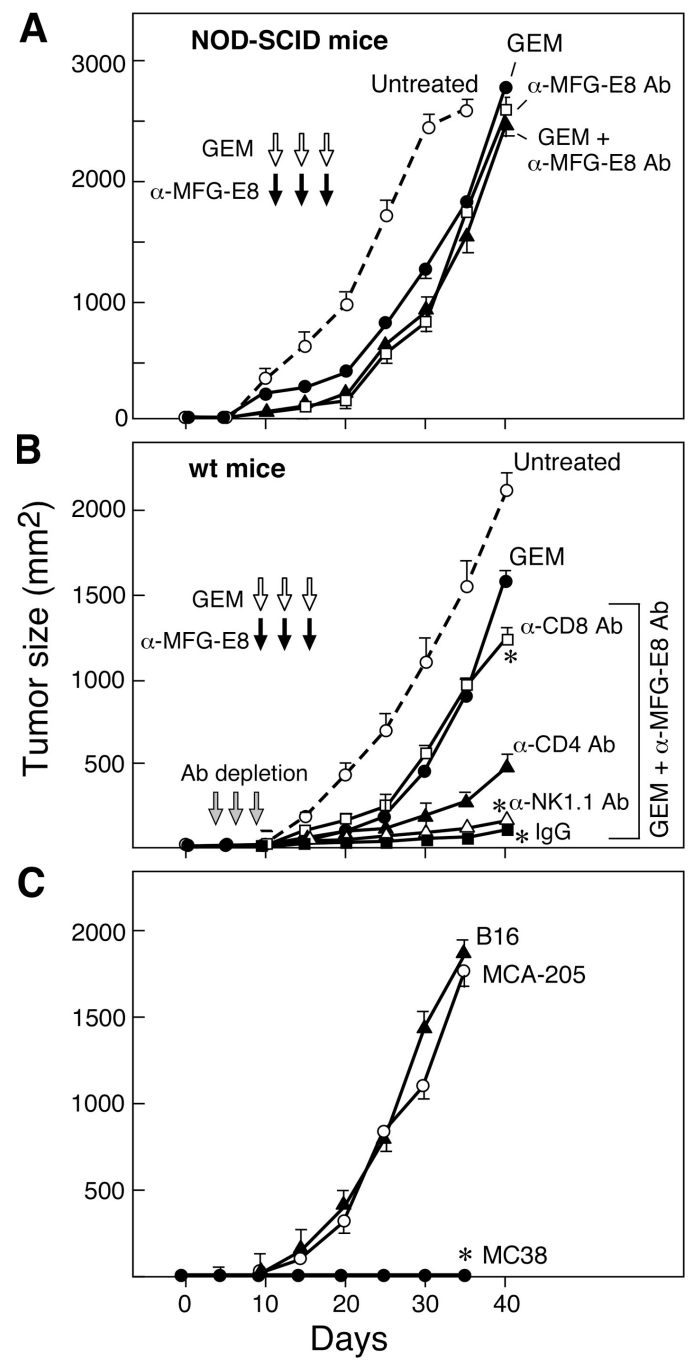

Figure 3. The therapeutic activity of MFG-E8 antibody blockade and chemotherapy involves host immunity. (A) NOD-SCID mice harboring established MC38 carcinomas $\left(25 \mathrm{~mm}^{2}\right)$ were treated with systemic gemcitabine (GEM) and anti-MFG-E8 mAb. (B) Established MC38 carcinomas bearing wild-type $\mathrm{C} 57 \mathrm{BL} / 6$ mice that were depleted of $\mathrm{CD} 4^{+}, \mathrm{CD} 8^{+}$, or NK1.1 $1^{+}$cells with antibodies were treated with systemic GEM and antiMFG-E8 mAb. (C) Wild-type C57BL/6 mice that had rejected established MC38 carcinomas with systemic GEM and anti-MFG-E8 mAb showed specific longterm protective immunity against subsequent challenge with MC38 cells during the follow-up period ( $>200$ d). Each experiment was performed with five mice per group, and similar results were observed for each panel in three independent experiments. Shown are the means \pm SEM for each cohort in a representative experiment. ${ }^{*}, \mathrm{P}<0.05$ between the treatment and control. our analysis of the tumor infiltrates raised the possibility that dendritic cell capture of tumor cells in situ might be important for $\mathrm{T}$ cell priming.

To study the impact of anti-MFG-E8 antibodies on dendritic cell cross-presentation in more detail, we used EL-4 thymoma cells engineered to express OVA (EG.7-OVA) (22) and the syngeneic C57BL/6 mice harboring a transgenic TCR specific for an MHC class II-presented OVA peptide (OT-II) (23). BMDCs efficiently ingested irradiated EG.7-OVA cells, and this was only minimally blocked by an antibody to $\alpha_{\mathrm{v}}$ integrins or MFG-E8, indicating that this pathway was not required for tumor cell uptake in this system (Fig. $5 \mathrm{~B}$ and not depicted). Although anti-MFG-E8 antibodies did not affect the overall phagocytosis of irradiated EG.7-OVA cells, a blocking antibody to $F c$ receptors but not to $\alpha_{v}$ integrins partially attenuated uptake. These results reveal that anti-MFG-E8 antibodies switch the receptor for MFG-E8-mediated tumor cell ingestion from $\alpha_{\mathrm{v}} \beta_{3} / \alpha_{\mathrm{v}} \beta_{5}$ integrins to $\mathrm{FC}_{\mathrm{C}}$ receptors.

Consistent with the ability of activating Fc receptors to trigger immune stimulation (24), the opsonization of EG.7-OVA cells with anti-MFG-E8 antibodies enhanced dendritic cell stimulation of OT-II TCR transgenic CD4 ${ }^{+} \mathrm{T}$ cells. This activation resulted in increased production of IFN- $\gamma$ (Fig. 5 C) but not IL-4 or IL-17 (not depicted). In contrast, anti-Fc receptor antibodies inhibited cross-priming, whereas anti- $\alpha_{\mathrm{v}}$ integrin antibodies augmented $\mathrm{T}$ cell responses when either irradiated EG.7-OVA cells alone or anti-MFG-E8 antibody opsonized, irradiated EG.7-OVA cells were fed to dendritic cells (Fig. 5 C). The antiMFG-E8 antibodies also increased cross-presentation to MHC class I-restricted OT-I CD8 ${ }^{+} \mathrm{T}$ cells, resulting in increased IFN- $\gamma$ production (Fig. S6). Collectively, these findings suggest that MFG-E8 blockade enhances Th1 antitumor responses.

To further examine the importance of MFG-E8 antibodymediated cross-priming in vivo, we injected irradiated EG.7OVA cells together with anti-MFG-E8 antibodies into the footpads of OT-I mice and measured OVA-specific T cell responses in the draining lymph nodes $5 \mathrm{~d}$ later. In some experiments, blocking anti-Fc $\gamma \mathrm{R}$ antibodies were coadministered to evaluate the role of FCR-mediated uptake for antigen presentation. Although the injection of anti-MFG-E8 antibodies enhanced specific $\mathrm{CD}^{+} \mathrm{T}$ cell IFN- $\gamma$ production, the concurrent administration of anti-Fc $\gamma \mathrm{R}$ antibodies substantially inhibited this response (Fig. 5 D). These results indicate that MFG-E8 blockade promotes cross-priming of antigen-specific $\mathrm{CD}^{+} \mathrm{T}$ cells primarily through FcR-mediated antigen uptake.

\section{MFG-E8 modulates dendritic cell cytokine production}

To further clarify the mechanisms underlying $\mathrm{T}$ cell stimulation, we examined the impact of MFG-E8 on dendritic cell cytokine production after the uptake of dying tumor cells. The addition of rMFG-E8 protein increased dendritic cell IL-10 secretion, whereas anti-MFG-E8 antibodies reduced IL-10 but enhanced IL-12, IL-23, and TNF- $\alpha$ production (Fig. $6 \mathrm{~A}$ ). The effects of MFG-E8 on cytokine profiles were blocked with the RMV-7 anti- $\alpha_{\mathrm{v}}$ integrin antibody (unpublished data), confirming the importance of $\alpha_{\mathrm{v}} \beta_{3}$ and $\alpha_{\mathrm{v}} \beta_{5}$ integrins in this response. 
To address the role of IL-12 in the immune stimulation with anti-MFG-E8 antibodies, we used IL-12p35-deficient mice in a series of in vivo and in vitro studies. The efficacy of anti-MFG-E8 antibodies and CPT-11 treatment against MC38 colon tumors was partially reduced in IL-12-deficient mice compared with wild-type controls (Fig. 6 B). Moreover, the anti-MFG-E8 antibody-mediated cross-presentation of EG.7-OVA cells to OT-II CD4 ${ }^{+}$T cells was slightly decreased with IL-12-deficient dendritic cells compared with wild-type controls (Fig. 6 C). These results suggest that IL-12 contributes to the anti-MFG-E8 antibody-triggered immunostimulation, but other cytokines and/or cell-surface molecules also play important roles.

\section{DISCUSSION}

Although substantial evidence demonstrates that cross talk between tumor cells and normal host elements is critical to carcinogenesis (25), most cancer therapies primarily target individual compartments. Small molecule inhibitors of oncogenic tyro- sine kinases and antibody blockade of VEGF serve as prototypes of rationally designed agents that antagonize major pathogenic mechanisms in cancer cells and the host, respectively $(26,27)$. Although these treatments afford important clinical benefits, most patients achieve only partial responses and eventually succumb to progressive disease caused by the emergence of drugresistant variants. However, analogous to the ways in which antimicrobial agents cooperate with host reactions to effectuate sterilizing immunity for some serious infections (28), cancer treatments might be significantly improved through concurrently targeting the tumor and host. The results presented in this paper illustrate the potential for systemic MFG-E8 antibody blockade in combination with conventional oncologic therapies to accomplish this dual targeting.

MFG-E8 promotes cancer progression through coordinated $\alpha_{\mathrm{v}} \beta_{3}$ integrin signaling in tumor cells, vascular elements, and infiltrating myeloid cells (12). Although the administration of anti-MFG-E8 antibodies alone resulted in only modest tumor destruction and immune stimulation, the coupling

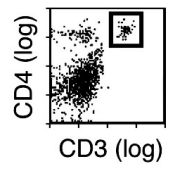

A
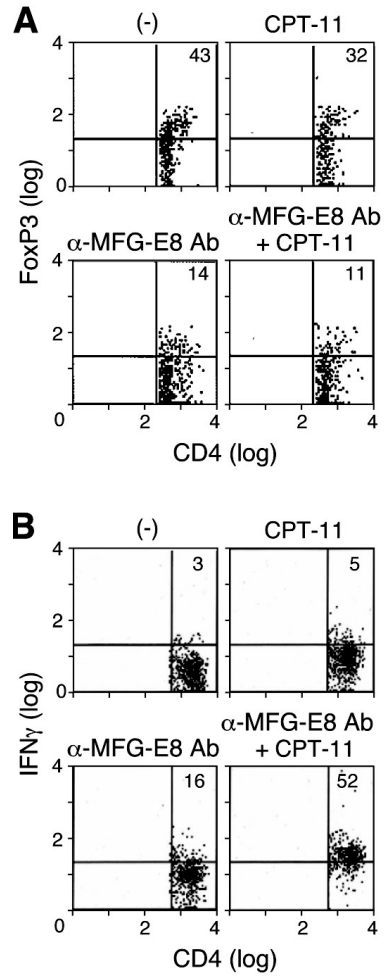
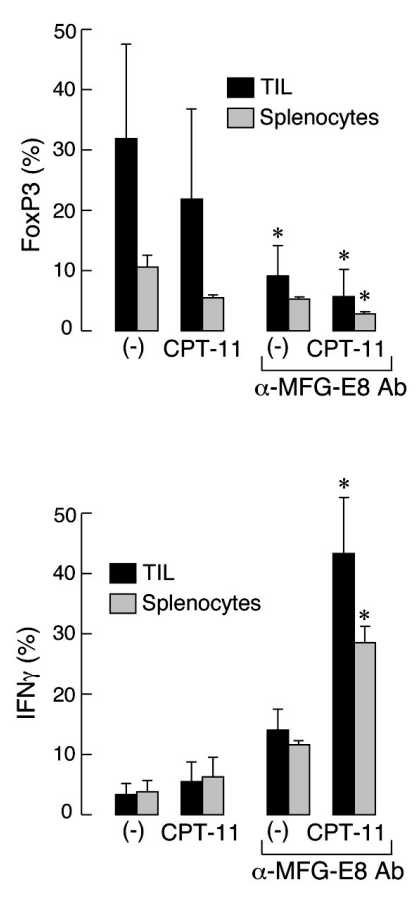
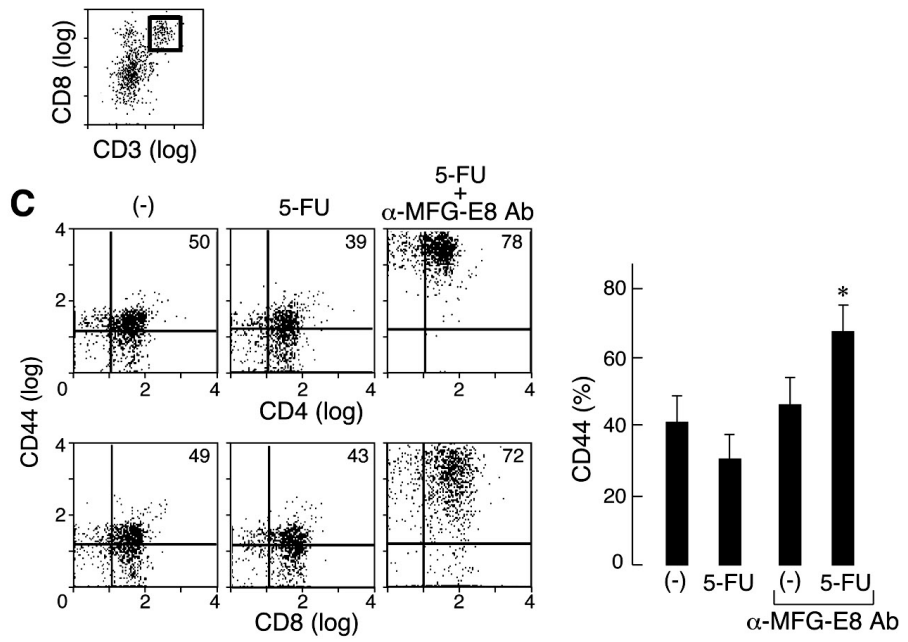

D

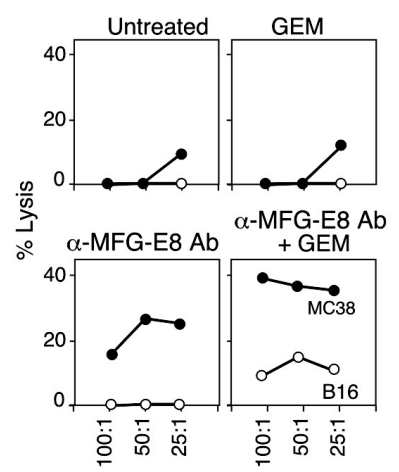

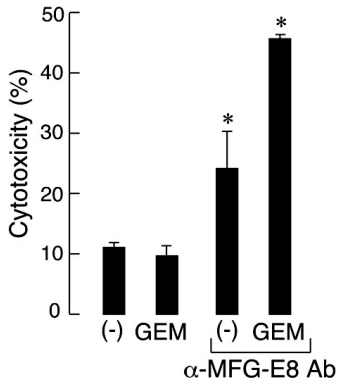

Figure 4. Combination MFG-E8 antibody blockade and chemotherapy enhances antitumor effector T cells and inhibits FoxP3+ $\mathrm{T}$ reg cells. Tumor-infiltrating lymphocytes (TILs) were harvested from mice bearing MC38 tumors $5 \mathrm{~d}$ after the indicated treatment. The TILs were gated as CD3 ${ }^{+} \mathrm{CD} 4^{+}$ or $\mathrm{CD} 3^{+} \mathrm{CD} 8{ }^{+} \mathrm{T}$ cells, and assayed for (A) FoxP3, (B) IFN- $\gamma$, and (C) CD44 expression with flow cytometry (percentages are shown). Representative stainings are presented. The means \pm SEM for six mice per group are shown in the adjacent panels. (D) Draining lymph nodes were harvested from MC38-bearing mice after the indicated treatments and evaluated for cytotoxic activity against ${ }^{51} \mathrm{Cr}$-labeled MC38 and B16 targets in vitro. The percent specific lysis is presented. Each experiment was independently performed four times. The means \pm SEM at an effector/target ratio of 100:1 for six mice per group are shown in the adjacent panels. ${ }^{*}, \mathrm{P}<0.05$ between the treatment and control. 
A
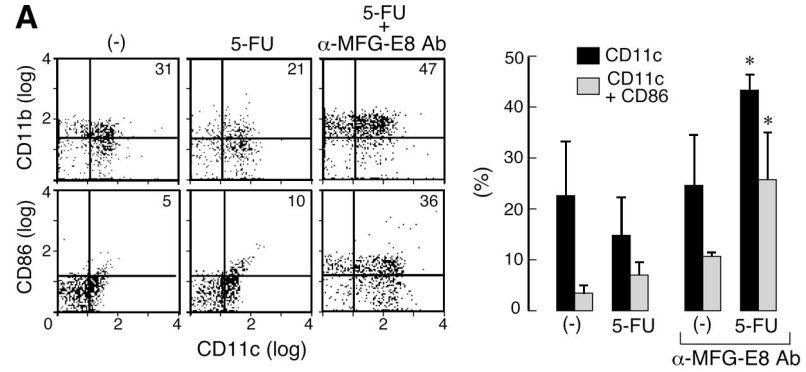

B
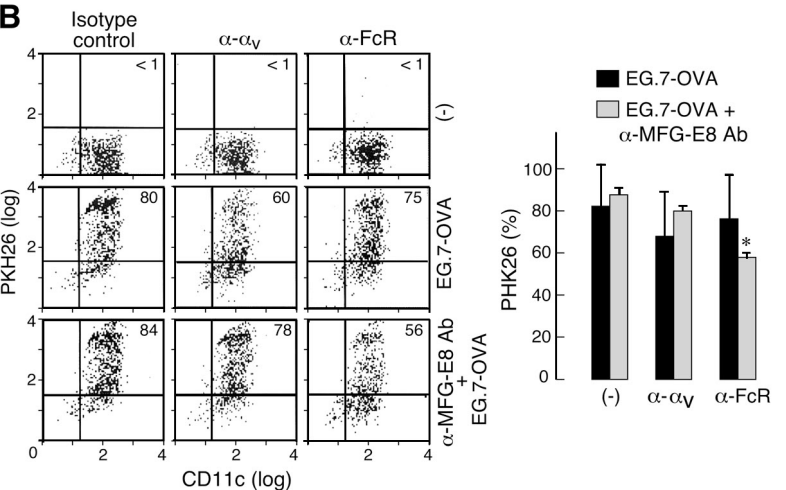

C
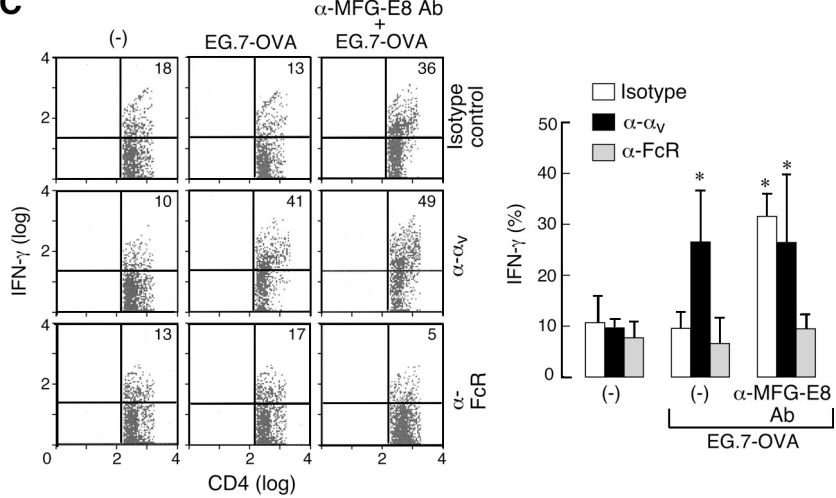

D

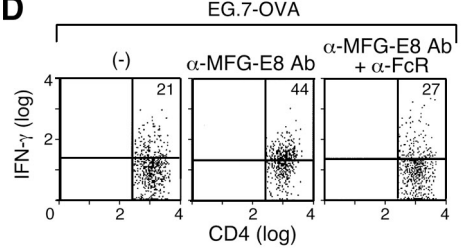

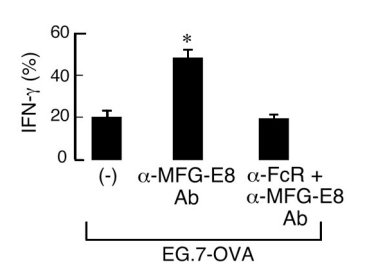

Figure 5. Anti-MFG-E8 antibodies enhance dendritic cell crosspresentation of dying tumor cells. (A) Tumor-infiltrating cells were harvested from mice harboring MC38 carcinomas $4 \mathrm{~d}$ after the indicated treatment. The $\mathrm{CD}^{+}$and $\mathrm{B} 22 \mathrm{O}^{+}$lymphocytes were excluded by gating, and the remaining forward/side scatter high cells were analyzed for CD11c, CD11b, and CD86 with flow cytometry (percentages are shown). Similar results were observed in three experiments. Shown to the right are the means \pm SEM for five mice per group. ${ }^{*}, P<0.05$. (B) BMDCs were cocultured with PKH26-labeled EG.7-OVA cells (with or without opsonization with anti-MFG-E8 mAbs) and evaluated for phagocytosis. The impact of blocking antibodies to $\alpha_{v}$ integrins and Fc receptors was determined (percentages are shown). Similar results were observed in three experiments, and the means \pm SEM are shown. ${ }^{*}, P<0.05$. (C) BMDCs that were loaded with EG.7-OVA cells as in B were co-cultured with OVA-specific

of drug-induced tumor cell death to MFG-E8 blockade effectuated the sustained regressions of established colon carcinomas, melanomas, and lymphomas. A key component of this therapeutic synergy is the ability of anti-MFG-E8 antibodies to attenuate tumor cell resistance to cytotoxic treatments, likely because of the inhibition of Akt activation. Some degree of intrinsic tumor cell sensitivity to the cytotoxic agent appears necessary for this enhancement, though, because gemcitabine, which failed to provoke B16 cell death in vitro (unpublished data), proved inactive in vivo in combination with MFG-E8 blockade. An additional mechanism by which anti-MFG-E8 antibodies might increase tumor cell killing, particularly in conjunction with anti-VEGFR-2 antibodies, may involve a more robust inhibition of the tumor blood supply, as MFG-E8 is required for VEGF-induced angiogenesis $(14,18)$. Moreover, knockdown of MFG-E8 in MC38 carcinoma cells exposed to chemotherapy also reduced VEGF production (unpublished data).

Upon the induction of tumor cell death in vivo with cytotoxic treatments, MFG-E8 blockade favored the establishment of an immunogenic tumor microenvironment. This conversion reflected the dual capacity of anti-MFG-E8 antibodies to antagonize $\alpha_{v} \beta_{3}$ integrin-driven immune suppression and to promote efficient $\mathrm{Fc}_{\mathrm{C}}$ receptor-mediated dendritic cell cross-presentation. In this context, recent analysis of mice harboring a myeloid cellspecific KO of $\alpha_{\mathrm{v}}$ integrins has underscored the importance of this receptor in attenuating inflammation (29), perhaps through the induction of Twist (12), an antagonist of the NF- $\mathrm{kB}$ pathway (30). Consistent with these results, we found that MFG-E8 blockade resulted in increased IL-12 production. This proinflammatory cytokine contributed to tumor protection, as revealed through studies of p35-deficient mice, although other factors such as IL-23, TNF- $\alpha$, and type I IFNs may play important roles as well. Accumulating evidence has also highlighted the ability of mAbs to opsonize tumor cells for efficient cross-presentation by dendritic cells, thereby engendering potent antitumor immunity (31). Collectively, these factors may promote the development of dense intratumoral infiltrates composed of abundant $\mathrm{CD}^{+}$and $\mathrm{CD}^{+}$effector $\mathrm{T}$ cells but only limited FoxP3 ${ }^{+}$ $\mathrm{T}$ reg cells. It is tempting to speculate that this broad $\mathrm{T}$ cell response may suppress the emergence of drug-resistant tumor cells and mediate long-term protection against tumor recurrence. In accordance with this idea, previous experimental and clinical studies have shown that a high ratio of effector $\mathrm{T}$ cells to $\mathrm{T}$ reg cells is tightly linked with sustained tumor destruction $(32,33)$.

TCR transgenic CD4+ $4^{+}$cells, and IFN- $\gamma$ production was evaluated with flow cytometry (percentages are shown). The effects of anti- $\alpha_{v}$ integrin and Fc receptor antibodies are shown. Similar results were observed in three experiments, and the means \pm SEM are shown to the right. ${ }^{*}, P<0.05$. (D) $10^{6}$ irradiated EG.7-OVA cells per mouse were injected into the footpads of OT-I mice with anti-MFG-E8, anti-Fc $\gamma R$, and isotype control antibodies as indicated. The draining lymph nodes were harvested after $5 d$, and $\mathrm{CD}^{+} \mathrm{T}$ cell IFN- $\boldsymbol{\gamma}$ production was determined with flow cytometry (percentages are shown). Similar results were observed in three experiments. Shown are the means \pm SEM. ${ }^{*}, \mathrm{P}<0.05$. 

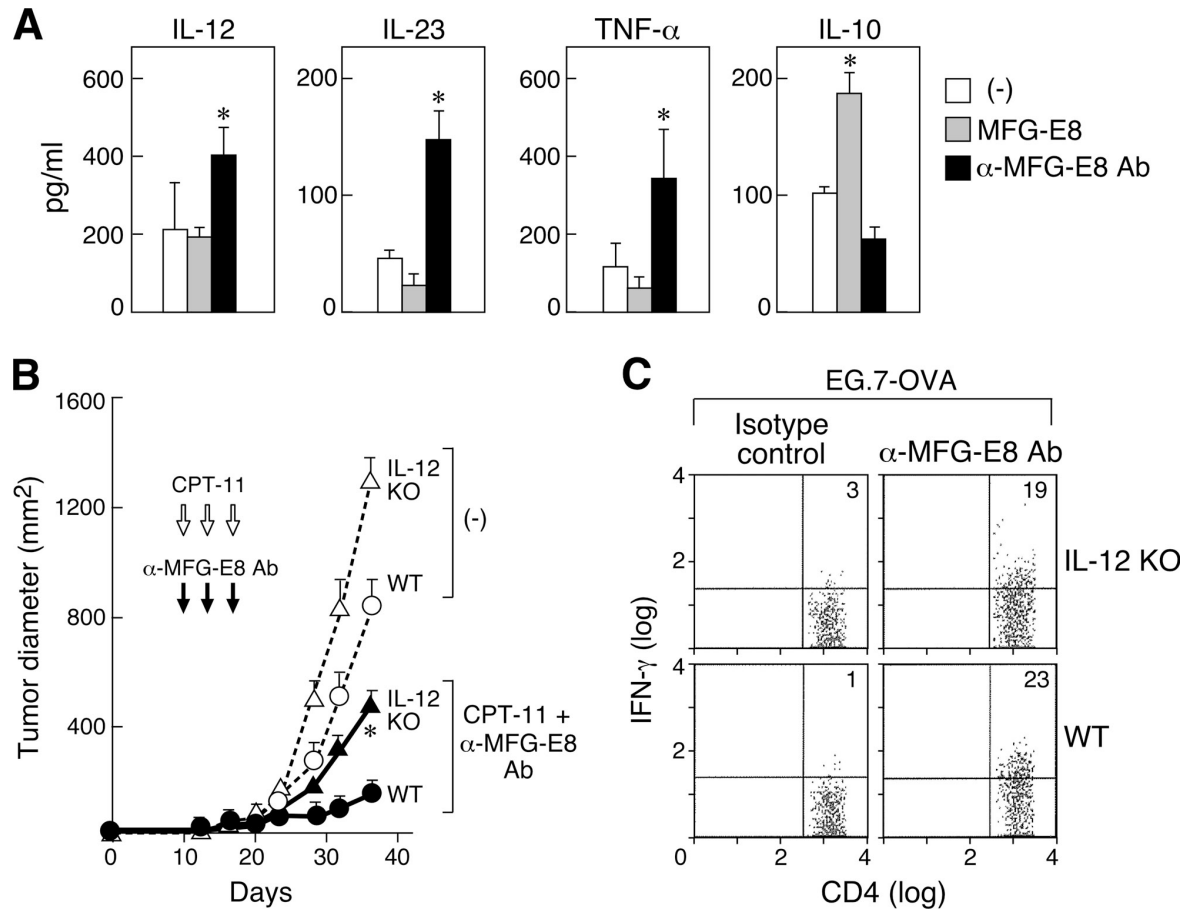

Figure 6. Anti-MFG-E8 antibodies modulate antigen-presenting cell cytokine profiles. (A) BMDCs were treated with recombinant MFG-E8 or anti-MFG-E8 mAbs, and cytokine production was determined with ELISA. Shown are the means \pm SEM for three experiments. ${ }^{*}$, P $<0.05$. (B) C57BL/6 wild-type or IL-12p35-deficient mice harboring established MC38 colon carcinomas (25 $\left.\mathrm{mm}^{2}\right)$ were treated with systemic gemcitabine with or without anti-MFG-E8 mAb, as shown in Fig. $1 \mathrm{~A}$. Shown are the means \pm SEM for five mice per group. Similar results were observed in a second experiment. ${ }^{*}, \mathrm{P}<0.05$ between treated wild-type and IL-12 KO mice. (C) BMDCs from wild-type or IL-12-deficient mice were loaded with EG.7-OVA cells and co-cultured with $C D 4^{+} T$ cells obtained from wild-type mice that were immunized with EG.7-OVA cells (five times). IFN- $\gamma$ production was evaluated by flow cytometry (percentages are shown). Similar results were observed in a second experiment.

Recent work has illustrated that some cytotoxic therapies, including anthracyclines and taxanes, may induce a form of immunogenic cell death in which the release of calreticulin and high mobility group box 1 from dying tumor cells serves as an innate activating signal (34-36). Cytotoxic therapies may additionally trigger the DNA damage response to up-regulate tumor cell expression of NKG2D ligands, thereby eliciting $\mathrm{NK}$ and $\mathrm{CD}^{+} \mathrm{T}$ cell responses (37). Moreover, agonistic antibodies to TNF-related apoptosis-inducing ligand receptors, which are frequently expressed on cancer cells, mediate potent antitumor effects in association with other immunotherapies $(38,39)$. Our results elucidate several novel antitumor mechanisms through which systemic MFG-E8 blockade may potentiate the efficacy of conventional oncologic therapies by coordinately targeting tumor cells and components of the tumor microenvironment. Perhaps the coupling of anti-MFG-E8 antibodies to tumor cell death might be considered a new strategy for in vivo cancer vaccination.

\section{MATERIALS AND METHODS}

Mice. C57BL/6, NOD-SCID, and OVA transgenic OT-II mice were obtained from SRL or the Jackson Laboratory and housed under specific pathogen-free conditions. OT-I and IL-12p35 gene KO mice were used as previously described $(40,41)$. All experiments were conducted according to a protocol approved by the review committee of animal research at the Institute of Medical Sciences of the University of Tokyo or Keio University School of Medicine.
In vivo tumor challenges. 6-wk-old C57BL/6, NOD-SCID, or IL-12 KO female mice were injected intradermally with $10^{5}$ MC38 colon carcinoma, B16 melanoma, EL-4 thymoma, or MCA205 fibrosarcoma cells. After the tumors grew to an approximate size of $25 \mathrm{~mm}^{2}$, the mice were treated with various therapeutic regimens. For the MC38 tumors, mice received on days 10, 12 , and $141 \mathrm{or} 4 \mathrm{mg} / \mathrm{ml}$ gemcitabine, $5 \mathrm{mg} / \mathrm{ml} 5-\mathrm{FU}, 1 \mathrm{mg} / \mathrm{ml} \mathrm{CPT-11,}$ $40 \mathrm{mg} / \mathrm{ml}$ of the VEGFR-2 mAb DC101 (ImClone Systems), or the $40 \mathrm{mg} / \mathrm{ml}$ of the EGFR tyrosine kinase inhibitor AG490 (MERCK). In some experiments, tumors were treated with five daily doses of irradiation (3 Gy at a rate of $4 \mathrm{~Gy} / \mathrm{min}$ ) using an isolator system. For the B16 tumors, mice were treated with $5 \mathrm{mg} / \mathrm{ml}$ doxorubicin, $2 \mathrm{mg} / \mathrm{ml}$ etoposide, or gemcitabine as described. For EL-4 thymoma cells, mice were treated with $5 \mathrm{mg} / \mathrm{ml}$ doxorubicin, as described. A hamster $\mathrm{mAb}$ against MFG-E8 ${ }^{1}$ (at $2 \mathrm{mg} / \mathrm{ml}$; MBL International), an isotype control immunoglobulin IgG2a, or $1 \mathrm{mg} / \mathrm{ml}$ of rabbit polyclonal anti-MFG-E8 sera (provided by C. Thèry, Institut National de la Santé et de la Recherche Médicale, Paris, France) $(17,18)$ were administered concurrently with the cytotoxic therapies. In some studies, mice were also treated with depleting antibodies against CD4 (clone GK1.5), CD8 (clone 53-6.72), and NK1.1 (PK-136; American Type Culture Collection) at days $-5,-3$, and 0 relative to the cytotoxic therapy $(40,42)$. Tumor growth was monitored regularly and the products of the perpendicular diameters were recorded.

Apoptosis assays. Tumor cells were cultured in serum-free media and treated with various cytotoxic agents overnight with or without anti-MFG-E8 antibodies. To generate stable drug-resistant variants, MC38 cells were cultured in gradually increasing concentrations of gemcitabine (from 1 to $20 \mu \mathrm{g} / \mathrm{ml}$ ) or CPT-11 (from 0.5 to $10 \mu \mathrm{g} / \mathrm{ml}$ ) over $\sim 8 \mathrm{wk}$. MFG-E8 expression was measured by flow cytometry using the hamster anti-MFG-E8 mAb followed by an anti-mouse IgG, as previously described (10). Secreted MFG-E8 levels 
were measured with an ELISA according to the manufacture's instruction (R\&D Systems). Cell death was determined with annexin V and propidium iodide staining, or DiOC6 labeling to quantify the mitochondrial membrane potential, according to the manufacturer's instructions (BD). To measure tumor apoptosis in vivo, we treated established MC38 or B16 tumors $\left(25 \mathrm{~mm}^{2}\right)$ with $10 \mathrm{mg} / \mathrm{ml}$ gemcitabine or dacarbazine with or without anti-MFG-E8 antibodies, harvested the tumors $4 \mathrm{~d}$ after therapy, and measured caspase $3 \mathrm{ac}-$ tivation in tumor homogenates with a colorimetric assay kit (Invitrogen).

Immune assays. Tumor-infiltrating lymphocytes were harvested with a cell gradient separation (Nocoprep; Axis-Shield), as previously described (10). Cell populations were characterized using mAbs against CD3, CD4, CD8, CD11b, CD11c, CD44, CD86, Gr-1, and Foxp3 (clone MF23). IFN- $\gamma$ production was measured by intracellular flow cytometry, as previously described (10). Cytotoxicity was measured by incubating lymphoid cells isolated from draining lymph nodes with irradiated MC38 cells for $96 \mathrm{~h}$ and then testing lytic activity against ${ }^{51} \mathrm{Cr}-$ labeled MC38 and B16 targets. The percent lysis was calculated as (experimental - spontaneous)/(maximum - spontaneous) $\times 100$, using $5 \%$ Triton $\mathrm{X}$ and medium alone for determination of the maximum and spontaneous counts.

BMDCs were cultured from bone marrow precursors using GM-CSFconditioned media for $7 \mathrm{~d}$ and were then treated with $100 \mathrm{ng} / \mathrm{ml}$ of recombinant MFG-E8 (R\&D Systems), $20 \mu \mathrm{g} / \mathrm{ml}$ anti-MFG-E8 mAb (MBL International), or $20 \mu \mathrm{g} / \mathrm{ml}$ of polyclonal MFG-E8 antiserum overnight. Culture supernatants were evaluated for IL-12, IL-23, TNF- $\alpha$, and IL-10 levels with ELISAs.

Cross-priming assays. Day 7 BMDCs were also co-cultured with irradiated EG.7-OVA cells (1:10 ratio) that were labeled with PKH26 (Sigma-Aldrich) in 12-well round-bottom plates, and phagocytosis was determined with flow cytometry. In some experiments, the tumor cells were pretreated with $30 \mathrm{mg} / \mathrm{ml}$ anti-MFG-E8 $\mathrm{mAb}$ for $30 \mathrm{~min}$ before the co-culture. The impact of blocking antibodies to $\alpha_{\mathrm{v}}$ integrins (clone RMV-7; Millipore) or Fc receptors (clone $2.4 \mathrm{G} 2$; BD) on tumor cell uptake was similarly evaluated. To antigen presentation by DCs, naive $\mathrm{CD} 4^{+} \mathrm{T}$ cells were isolated from the spleens of OT-I or OT-II mice by magnetic cell sorting (Miltenyi Biotec) and added to the tumor cell-loaded dendritic cells for $24 \mathrm{~h}$. Intracellular IFN- $\gamma$ expression in T cells was then determined by flow cytometry.

For in vivo cross-priming assays, $10^{6}$ irradiated EG.7-OVA cells per mouse were injected into the footpads of OT-I mice with $1 \mathrm{mg} / \mathrm{ml}$ anti-MFG-E8 $\mathrm{mAb}, 1 \mathrm{mg} / \mathrm{ml}$ anti-FcR blocking antibody (clone 2.4G2), or isotype control. $5 \mathrm{~d}$ after the challenge, mice were sacrificed, and the draining lymph node cells were isolated and cultured with $10 \mathrm{mg} / \mathrm{ml}$ MHC class I-restricted OVA peptides overnight. IFN- $\gamma$ production by $\mathrm{CD}^{+} \mathrm{T}$ cells was then determined by flow cytometry or ELISA using the culture supernatants.

Statistical analysis. Statistical analysis was performed using the unpaired Student's $t$ test or one-way analysis of variance through all of the experimental procedures. Differences were considered significant when the p-value was $<0.05$.

Online supplemental material. Fig. S1 associates temporal relationships of anti-MFG-E8 antibody and chemotherapy administration in antitumor responses. Fig. S2 presents in vivo antitumor activities of anti-MFG-E8 antibody and doxorubicin against established EL-4 thymomas. Fig. S3 shows the humeral responses induced by in vivo treatment of anti-MFG-E8 antibody and chemotherapy. Fig. S4 shows the frequency of $\mathrm{CD} 11 \mathrm{~b}^{+}$and $\mathrm{CD} 11 \mathrm{~b}^{+} \mathrm{Gr}-1^{+}$myelid cells at tumors with the treatments. Fig. S5 suggests the in vitro phagocytosis of apoptotic tumor cells by BMDCs. In Fig. S6, the effect of anti-MFG-E8 antibody was examined in mediating in vitro cross-presentation of OVA antigen to OT-I T cells by BMDCs. Online supplemental material is available at http://www.jem.org/cgi/content/full/jem.20082614/DC1

We wish to thank Dr. Clotilde Therry for valuable advice in the making of rabbit polyclonal antibody against mouse MFG-E8; A. Kurose for her secretarial assistance; and S. Nakayama, A. Asami and R. Miyake for assistance with the in vivo tumor study, ELISA assay, and animal care. M. Jinushi, G. Dranoff, and H. Tahara were responsible for experimental design; M. Jinushi, M. Sato, and S. Nagai were responsible for the preparation and performance of experiments; data analysis and interpretation were performed by M. Jinushi, M. Sato, A. Kanamoto, A. Itoh, S. Nagai, S. Koyasu, G. Dranoff, and H. Tahara; and M. Jinushi, G. Dranoff, and H. Tahara prepared the manuscript.

This study was supported in part by the Grants-in-Aid for Scientific Research on Priority Areas (20015016 to H. Tahara) and for Young Scientists (Start-Up; 20890050 to M. Jinushi) from the Ministry of Education, Culture, Sports, Science and Technology of Japan, as well as by the Melanoma Research Alliance and the Research Foundation for the Treatment of Ovarian Cancer (G. Dranoff).

The authors have no conflicting financial interests.

Submitted: 19 November 2008

Accepted: 17 April 2009

\section{REFERENCES}

1. Dranoff, G. 2004. Cytokines in cancer pathogenesis and cancer therapy. Nat. Rev. Cancer. 4:11-22.

2. de Visser, K.E., A. Eichten, and L.M. Coussens. 2006. Paradoxical roles of the immune system during cancer development. Nat. Rev. Cancer. 6:24-37.

3. Balkwill, F., K.A. Charles, and A. Mantovani. 2005. Smoldering and polarized inflammation in the initiation and promotion of malignant disease. Cancer Cell. 7:211-217.

4. Smyth, M.J., G.P. Dunn, and R.D. Schreiber. 2006. Cancer immunosurveillance and immunoediting: the roles of immunity in suppressing tumor development and shaping tumor immunogenicity. Adv. Immunol. 90:1-50.

5. Karin, M., and F.R. Greten. 2005. NF-kappaB: linking inflammation and immunity to cancer development and progression. Nat. Rev. Immunol. 5:749-759.

6. Yu, H., M. Kortylewski, and D. Pardoll. 2007. Crosstalk between cancer and immune cells: role of STAT3 in the tumour microenvironment. Nat. Rev. Immunol. 7:41-51.

7. Rakoff-Nahoum, S., and R. Medzhitov. 2007. Regulation of spontaneous intestinal tumorigenesis through the adaptor protein MyD88. Science. 317:124-127.

8. Naugler, W.E., T. Sakurai, S. Kim, S. Maeda, K. Kim, A.M. Elsharkawy, and M. Karin. 2007. Gender disparity in liver cancer due to sex differences in MyD88-dependent IL-6 production. Science. 317:121-124.

9. Jinushi, M., F.S. Hodi, and G. Dranoff. 2008. Enhancing the clinical activity of granulocyte-macrophage colony-stimulating factor-secreting tumor cell vaccines. Immunol. Rev. 222:287-298.

10. Jinushi, M., Y. Nakazaki, M. Dougan, D.R. Carrasco, M. Mihm, and G. Dranoff. 2007. MFG-E8 mediated uptake of apoptotic cells by APCs links the pro- and anti-inflammatory activities of GM-CSF. J. Clin. Invest. 117:1902-1913.

11. Hanayama, R., M. Tanaka, K. Miwa, A. Shinohara, A. Iwamatsu, and S. Nagata. 2002. Identification of a factor that links apoptotic cells to phagocytes. Nature. 417:182-187.

12. Jinushi, M., Y. Nakazaki, D.R. Carrasco, D. Draganov, N. Souders, M. Johnson, M.C. Mihm, and G. Dranoff. 2008. Milk fat globule EGF-8 promotes melanoma progression through coordinated Akt and Twist signaling in the tumor microenvironment. Cancer Res. 68:8889-8898.

13. Miller, A.J., and M.C. Mihm Jr. 2006. Melanoma. N. Engl. J. Med. 355:51-65.

14. Neutzner, M., T. Lopez, X. Feng, E.S. Bergmann-Leiner, W.W. Leiner, and M.C. Udey. 2007. MFG-E8/lactadherin promotes tumor growth in an angiogenesis-dependent transgenic mouse model of multistage carcinogenesis. Cancer Res. 67:6777-6785.

15. Carmon, L., I. Bobilev-Priel, B. Brenner, D. Bobilev, A. Paz, E. Bar-Haim, B. Tirosh, T. Klein, M. Fridkin, F. Lemonnier, et al. 2002. Characterization of novel breast carcinoma-associated BA46-derived peptides in HLA-A2.1/ D(b)-beta2m transgenic mice. J. Clin. Invest. 110:453-462.

16. Meyerhardt, J. A., and R.J. Mayer. 2005. Systemic therapy for colorectal cancer. N. Engl. J. Med. 352:476-487.

17. Bu, H.F., X.L. Zuo, X. Wang, M.A. Ensslin, V. Koti, W. Hsueh, A.S Raymond, B.D. Shur, and X.D. Tan. 2007. Milk fat globule-EGF factor8/lactadherin plays a crucial role in maintenance and repair of murine intestinal epithelium. J. Clin. Invest. 117:3673-3683. 
18. Silvestre, J.S., C. Thery, G. Hamard, J. Boddaert, B. Aquilar, A. Delcayre, C. Houbron, R. Tamarat, O. Blanc-Brude, S. Heeneman, et al. 2005. Lactadherin promotes VEGF-dependent neovascularization. Nat. Med. 11:499-506.

19. Hanayama, R., M. Tanaka, K. Miyasaka, K. Aozasa, M. Koike, Y. Uchiyama, and S. Nagata. 2004. Autoimmune disease and impaired uptake of apoptotic cells in MFG-E8-deficient mice. Science. 304:1147-1150.

20. Miyasaka, K., R. Hanayama, M. Tanaka, and S. Nagata. 2004. Expression of milk fat globule epidermal growth factor 8 in immature dendritic cells for engulfment of apoptotic cells. Eur. J. Immunol. 34:1414-1422.

21. Kranich, J., N.J. Krautler, E. Heinen, M. Polymenidou, C. Bridel, A. Schildkecht, C. Huber, M.H. Kosco-Vibois, R. Zinkernagel, G. Miele, and A. Aquzzi. 2008. Follicular dendritic cells control engulfment of apoptotic bodies by secreting Mfge8. J. Exp. Med. 205:1293-1302.

22. Moore, M.W., F.R. Carbone, and M.J. Bevan. 1988. Introduction of soluble protein into the class I pathway of antigen processing and presentation. Cell. 54:777-785.

23. Murphy, K.M., A.B. Heimberger, and D.Y. Loh. 1990. Induction by antigen of intrathymic apoptosis of CD4+CD8+TCRlo thymocytes in vivo. Science. 250:1720-1723.

24. Kalergis, A.M., and J.V. Ravetch. 2002. Inducing tumor immunity through the selective engagement of activating Fc $\gamma$ receptors on dendritic cells. J. Exp. Med. 195:1653-1659.

25. Coussens, L.M., and Z. Werb. 2002. Inflammation and cancer. Nature. 420:860-867.

26. Druker, B.J., and A. David. 2003. Karnofsky Award lecture. Imatinib as a paradigm of targeted therapies. J. Clin. Oncol. 21(23 Suppl.):239s-245s.

27. Ferrara, N. 2004. Vascular endothelial growth factor: basic science and clinical progress. Endocr. Rev. 25:581-611.

28. Rubin, R.H., and L.S. Young. 2002. Clinical Approach to Infection in the Compromised Host. Springer-Verlag New York Inc., New York. 100 pp.

29. Lacy-Hulbert, A., A.M. Smith, H. Tissire, M. Barry, D. Crowley, R.T. Bronson, J.T. Roes, J.S. Savill, and R.O. Hynes. 2007. Ulcerative colitis and autoimmunity induced by loss of myeloid alphav integrins. Proc. Natl. Acad. Sci. USA. 104:15823-15828.

30. Sosic, D., J.A. Richardson, K. Yu, D.M. Ornitz, and E.N. Olson. 2003. Twist regulates cytokine gene expression through a negative feedback loop that represses NF-kappaB activity. Cell. 112:169-180.

31. Dhodapkar, K.M., and M.V. Dhodapkar. 2005. Recruiting dendritic cells to improve antibody therapy of cancer. Proc. Natl. Acad. Sci. USA. 102:6243-6244.
32. Quezada, S.A., K.S. Peggs, M.A. Curran, and J.P. Allison. 2006 CTLA4 blockade and GM-CSF combination immunotherapy alters the intratumor balance of effector and regulatory $\mathrm{T}$ cells. J. Clin. Invest. 116:1935-1945

33. Hodi, F.S., M. Butler, D.A. Oble, M.V. Seiden, F.G. Haluska, A. Kruse, S. Macrae, M. Nelson, C. Canning, I. Lowy, et al. 2008. Immunologic and clinical effects of antibody blockade of cytotoxic T lymphocyte-associated antigen 4 in previously vaccinated cancer patients. Proc. Natl. Acad. Sci. USA. 105:3005-3010.

34. Obeid, M., A. Tesniere, F. Ghiringhrlli, G.M. Fimia, L. Apetoh, J.L. Perfettini, M. Castedo, G. Miqnot, T. Panaretakis, N. Casares, et al. 2007. Calreticulin exposure dictates the immunogenicity of cancer cell death. Nat. Med. 13:54-61.

35. Apetoh, L., F. Ghiringhelli, A. Tesniere, M. Obeid, C. Ortiz, A. Criollo, G. Mignot, M.C. Maiuri, E. Ullrich, P. Saulnier, et al. 2007. Toll-like receptor 4-dependent contribution of the immune system to anticancer chemotherapy and radiotherapy. Nat. Med. 13:1050-1059.

36. Hynes, N.M., R.G. van der Most, R.A. Lake, and M.J. Smyth. 2008. Immunogenic anti-cancer chemotherapy as an emerging concept. Curr. Opin. Immunol. 20:545-557.

37. Gasser, S., and D.H. Raulet. 2006. The DNA damage response arouses the immune system. Cancer Res. 66:3959-3962.

38. Uno, T., K. Takeda, Y. Kojima, H. Yoshizawa, H. Akiba, R.S. Mittler, F. Geyjo, K. Okumura, H. Yagita, and M.J. Smyth. 2006. Eradication of established tumors in mice by a combination antibody-based therapy. Nat. Med. 12:693-698.

39. Johnstone, R.W., A.J. Fraw, and M.J. Smyth. 2008. The TRAIL apoptotic pathway in cancer onset, progression and therapy. Nat. Rev. Cancer. 8:782-798.

40. Kaiga, T., M. Sato, H. Kaneda, Y. Iwakura, T. Takayama, and H. Tahara. 2007. Systemic administration of Il-23 induces potent antitumor immunity primarily mediated through Th1-type response in association with the endogenously expressed IL-12. J. Immunol. 178:7571-7580.

41. Hogquist, K.A., S.C. Jameson, W.R. Heath, J.L. Howard, M.J. Bevan, and F.R. Carbone. 1994. T cell receptor antagonist peptides induce positive selection. Cell. 76:17-25.

42. Dranoff, G., E. Jaffee, A. Lazenby, P. Golumbek, H. Levitsky, K. Brose, V. Jackson, H. Hamada, D. Pardoll, and R.C. Mulligan. 1993. Vaccination with irradiated tumor cells engineered to secrete murine granulocyte-macrophage colony-stimulating factor stimulates potent, specific, and long-lasting anti-tumor immunity. Proc. Natl. Acad. Sci. USA. 90:3539-3543. 